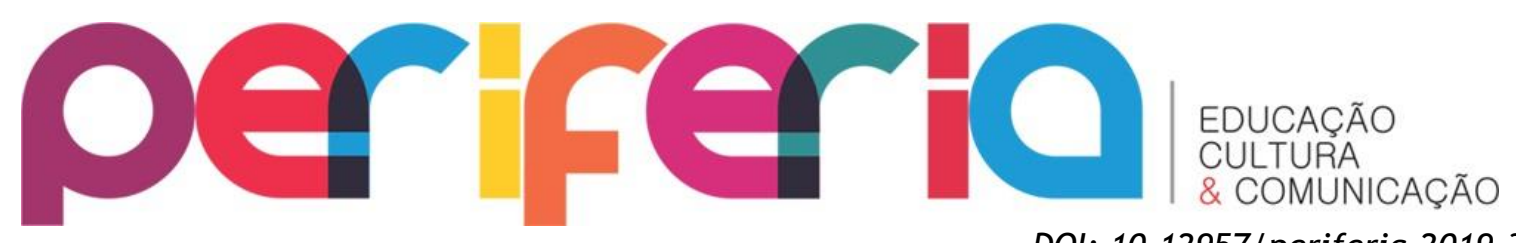

DOI: $10.12957 /$ periferia.2019.37016

\title{
MEMES DE INTERNET E EDUCAÇÃO: UMA SEQUÊNCIA DIDÁTICA PARA AS AULAS DE HISTÓRIA E LÍNGUA PORTUGUESA
}

\author{
Maria Alice de Souza ${ }^{1}$ \\ Universidade do Estado de Minas Gerais - UEMG
}

\section{Resumo}

Um dos desafios da educação contemporânea é promover práticas que oportunizem a participação crítica do educando em atividades próprias da cultura digital. Dessa forma, objetivando, de um lado, legitimar as vivências trazidas pelos aprendizes e, por outro, refletir sobre as características do texto digital, o presente artigo apresenta uma sequência didática desenvolvida com alunos do ensino médio de uma escola pública da rede estadual do município de Belo Horizonte no Estado de Minas Gerais utilizando o meme de internet. Ora, conhecido pela combinação de imagens vinculadas a legendas com teor normalmente irônico ou bem-humorado, o meme de internet tornou-se bem popular entre os jovens, propagando determinada ideia, piada ou comportamento. Mediante revisão bibliográfica, este trabalho apresenta ainda uma visão concisa do meme de internet, considerando sua estrutura, tipos de enunciados, inserção sociocultural e práticas sociais a ele atreladas. Assim, para apresentar a história de constituição social do meme, recorreu-se a Dawkins (1978); Dennett (1998); Blackmore (2002); Recuero (2007); Jenkins (2009); Sales (2010); Souza Junior (2014); Shifman (2014); Barreto (2015); Escalante (2016); Chagas (2016). Com o intuito de situar o uso do meme de acordo com as demandas sociais, o texto apresenta as considerações de Soares (2002); Xavier (2005); Coscarelli (2006); Rojo (2009); Euzébio e Cerutti-Rizzatti (2013); Ribeiro (2017). Ao final da experiência, percebe-se que longe de ser um gênero voltado apenas para a fruição, o meme de internet porta teor crítico, possuindo um grande potencial didático.

Palavras-chave: meme de internet; práticas sociais; sequência didática

\footnotetext{
${ }^{1}$ Mestranda em Educação e Formação Humana na Universidade do Estado de Minas Gerais. Graduada em Letras pela Universidade Federal de Minas Gerais (1996), possui especialização em Educação, Mídias e Tecnologias pela Universidade do Estado de Minas Gerais (2007). Atualmente leciona Língua Portuguesa na Escola Estadual Maria de Lourdes de Oliveira. mariaalicepos@gmail.com
} 


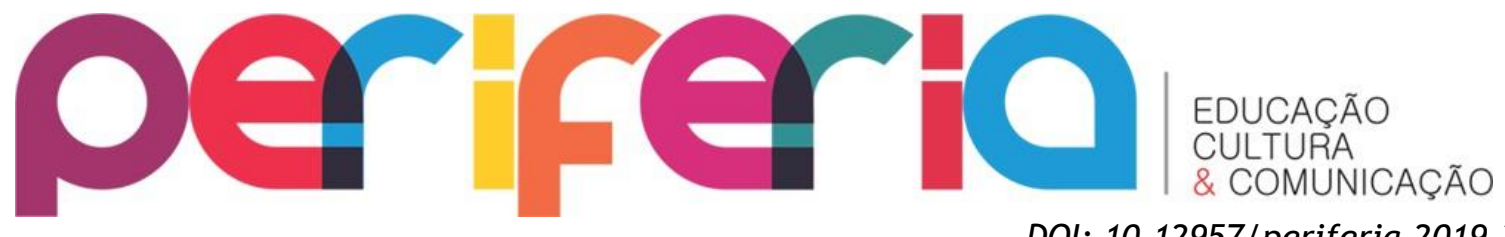

DOI: $10.12957 /$ periferia.2019.37016

\title{
INTERNET MEMES AND EDUCATION: A DIDACTIC SEQUENCE FOR THE LESSONS OF HISTORY AND PORTUGUESE LANGUAGE
}

\begin{abstract}
One of the challenges of contemporary education is to promote practices that allow the student's critical participation in activities of the digital culture. Thus, aiming, on the one hand, to legitimize the experiences brought by the learners and, on the other hand, to reflect on the characteristics of the digital text, this article presents a didactic sequence developed with high school students of a public school of the state's municipal network of Belo Horizonte in the State of Minas Gerais using the internet meme. Well, known for combining subtitle-related images with usually ironic or humorous content, the internet meme has become very popular with young people, propagating a certain idea, joke or behavior. Through a bibliographic review, this work presents a concise view of the internet meme, considering its structure, types of statements, socio-cultural insertion and social practices linked to it. Thus, to present the history of social constitution of the meme, it was appealed to Dawkins (1978); Dennett (1998); Blackmore (2002); Recuero (2007); Jenkins (2009); Sales (2010); Souza Junior (2014); Shifman (2014); Barreto (2015); Escalante (2016); Chagas disease (2016). In order to situate the use of the meme according to the social demands, the text presents the considerations of Soares (2002); Xavier (2005); Coscarelli (2006); Rojo (2009); Euzébio and Cerutti-Rizzatti (2013); Ribeiro (2017). At the end of the experiment, it is perceived that far from being a genre focused only on fruition, the internet meme is critical, possessing great didactic potential.
\end{abstract}

Keywords: internet meme; social practices; following teaching 


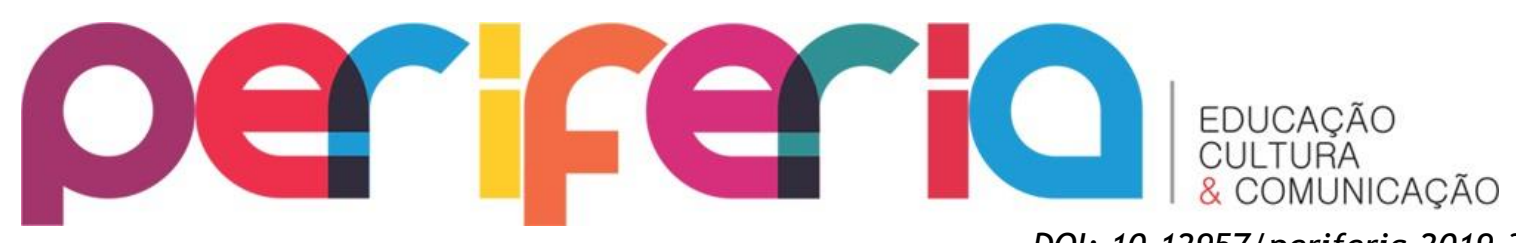

MEMES DE INTERNET Y EDUCACIÓN: UNA SECUENCIA PARA LA ENSEÑANZA DE LECCIONES DE LA HISTORIA Y LA LENGUA PORTUGUESA

\section{Resumen}

Uno de los desafíos de la educación contemporánea es promover prácticas que oportunicen la participación crítica del educando en actividades propias de la cultura digital. De esta forma, objetivando, por un lado, legitimar las vivencias traídas por los aprendices y, por otro, reflexionar sobre las características del texto digital, el presente artículo presenta una secuencia didáctica desarrollada con alumnos de la enseñanza media de una escuela pública de la red estatal del municipio de Belo Horizonte en el Estado de Minas Gerais utilizando el meme de internet. Ahora bien, conocido por la combinación de imágenes vinculadas a leyendas con contenido normalmente irónico o bien humorado, el meme de internet se ha vuelto muy popular entre los jóvenes, propagando cierta idea, chiste o comportamiento. Por medio de la revisión bibliográfica, este trabajo presenta una visión concisa del meme de internet, considerando su estructura, tipos de enunciados, inserción sociocultural y prácticas sociales a él acopladas. Así, para presentar la historia de constitución social del meme, se recurrió a Dawkins (1978); Dennett (1998); Blackmore (2002); Recuero (2007); Jenkins (2009); Sales (2010); Souza Junior (2014); Shifman (2014); Barreto (2015); Escalante (2016); Chagas (2016). Con el fin de situar el uso del meme de acuerdo con las demandas sociales, el texto presenta las consideraciones de Soares (2002); Xavier (2005); Coscarelli (2006); Rojo (2009); Euzébio y Cerutti-Rizzatti (2013); Ribeiro (2017). Al final de la experiencia, se percibe que lejos de ser un género volcado sólo para la fruición, el meme de internet porta contenido crítico, poseyendo un gran potencial didáctico.

Palabras clave: meme de internet; prácticas sociales; secuencia didáctica 


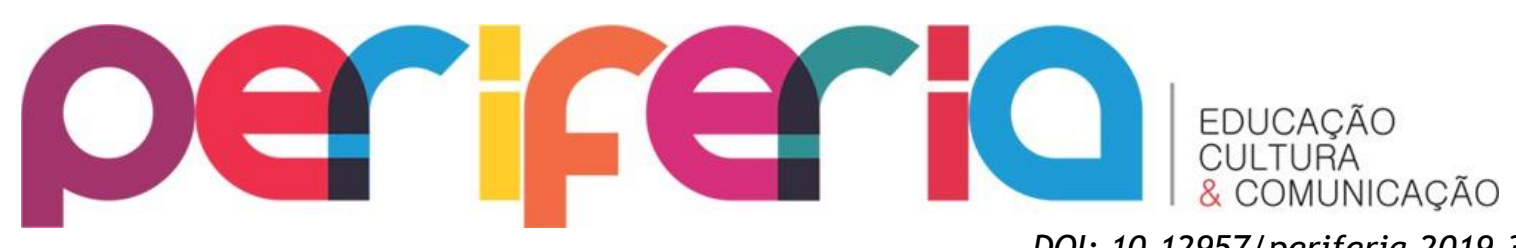

1. INTRODUÇÃO

DOI: $10.12957 /$ periferia.2019.37016

As tecnologias digitais se tornaram elemento sem o qual a comunicação e a cultura contemporânea são impensáveis. Ao se infiltrarem nas relações sociais, transformaram a natureza da comunicação humana, redefinindo as organizações sociais. E, ao incorporarem elementos da vida social, transcenderam a dimensão técnica, tornando, assim, expressão cultural das sociedades. Além disso, por elas, os sujeitos percebem, compreendem, criam, adaptam-se, organizando e produzindo insumos, produtos e serviços. Desse modo, percebido não apenas como infraestrutura material da comunicação digital, o ciberespaço é lugar para trocas de informações que instauram outras maneiras de interações sociais dos sujeitos (LEVY, 1999; LEMOS, 2003; SALES, 2010).

Nesse contexto, enquanto evento social da cultura letrada, a escrita tem sido usada para os mais distintos fins e nas mais diversas situações interacionais. Com efeito, as tecnologias digitais trouxeram para os eventos da cultura escrita novas nuances relacionadas ao prestígio, modos de publicação e circulação, rompendo com a visão de uma produção voltada apenas para a erudição e escolarização (ROJO, 2009; RIBEIRO, 2013; EUZÉBIO E CERUTTI-RIZZATTI, 2013).

Logo, diante do desafio de atender as demandas sociais que se voltam para o uso das tecnologias digitais de informação e comunicação (TDIC), a escola precisa promover práticas pedagógicas que envolvam os educandos em atividades que desenvolvam sua criticidade (LEU et al, 2013). Em outras palavras, apropriar-se de práticas que contemplem o gênero digital, é buscar a partir dos novos letramentos uma educação transformadora que valorize o protagonismo dos aprendizes.

Em vista disso, rompendo com a visão de uma aula voltada apenas para a erudição, foi que se idealizou uma sequência didática, em que os componentes curriculares História e Língua portuguesa se articulassem em torno do gênero digital "meme de internet". Se para o estudo de História, esse artefato contribui para uma reflexão a respeito dos eventos ocorridos na vida dos educandos; em Língua Portuguesa, ele permite averiguar os usos sociais da leitura e da escrita nos ambientes digitais. 


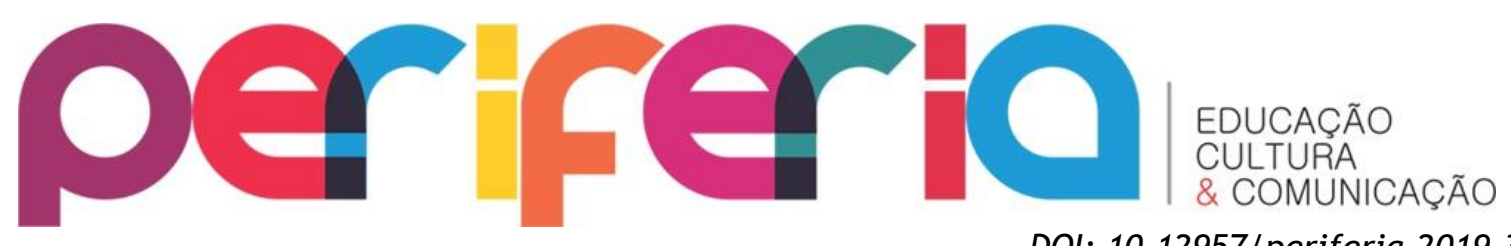

Nesse sentido, quanto ao procedimento metodológico, este artigo se caracteriza, por um lado, como revisão de literatura com um recorte qualitativo, por apresentar um levantamento e seleção bibliográficos de material já publicado até o momento sobre o assunto apresentado (MARCONI E LAKATOS, 2010); e, por outro, como relato de experiência, por compartilhar uma sequência didática desenvolvida com alunos do ensino médio de uma escola pública da rede estadual do município de Belo Horizonte.

Com este trabalho, a partir de um recorte teórico, intenciona-se ainda penetrar nas características e particularidades do meme de internet, já que sua proliferação reúne os indivíduos em torno de interesses comuns (BARRETO, 2015; ESCALANTE, 2016). A finalidade da sequência didática também foi a de compreender o meme de internet como prática comunicativa, que abarca diversas esferas da vida contemporânea (EUZÉBIO E CERUTTI-RIZZATTI, 2013).

Salienta-se ainda que este texto foi estruturado em quatro partes. $\mathrm{Na}$ introdução, delimitou-se o assunto, apresentando os objetivos e a metodologia empregada. Na segunda parte, a origem do termo meme foi revisitada e a evolução do conceito até os dias de hoje evidenciada. Essa seção, além de descrever, identificar e classificar os tipos de meme de internet, conforme duas estudiosas do tema, trouxe considerações de renomados autores sobre as particularidades do gênero. Na terceira parte, não apenas foram recordados os conceitos de práticas sociais envolvendo a leitura e escrita de memes de internet, como também apresentada uma sequência didática em que aspectos relacionados à leitura e à produção desse artefato foram explicitados. Por fim, nas considerações finais, retomaram-se sinteticamente as principais ideias expostas ao longo do texto.

\section{MEMES DE INTERNET: UMA EXPERIÊNCIA CONTEMPORÂNEA}

Embora, na internet, a palavra “meme” tenha aparecido na década de 90, quando o site criado por Joshua Schachter - o Memepool - reunia conteúdos e links que se proliferavam pela rede, foi etólogo Richard Dawkins (1978), na obra $O$ gene egoísta, que ao teorizar sobre evoluções culturais e genéticas, criou o vocábulo para 


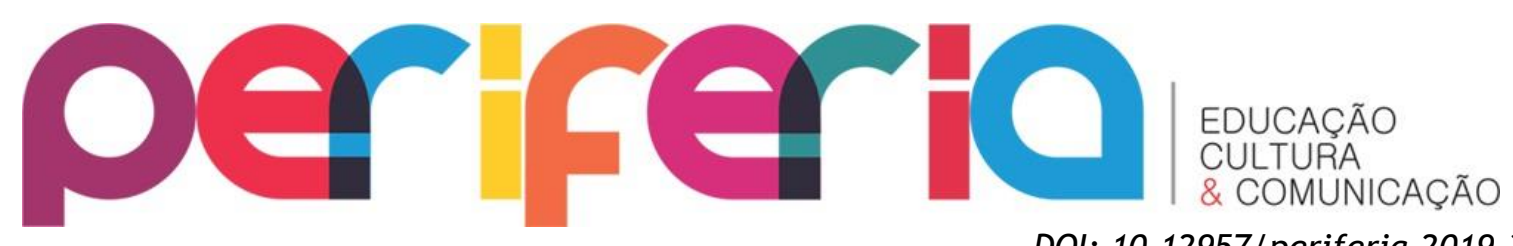

DOI: $10.12957 /$ periferia.2019.37016 designar a unidade de cultura que se propagava de uma mente para outra. 0 neologismo proveniente da forma em inglês "mimeme", originado do grego “mimema”, da mesma raiz de "mimese" (imitação), apresentava ainda, para o biólogo evolucionista, semelhanças com as palavras "gene" e "memória” (DAWKINS, 1978; HORTA, 2015).

No entanto, o termo começou a se metamorfosear a partir de seu surgimento. Assim, na década de 90, os memes foram considerados artefatos informacionais com atitude (DENNETT, 1998), transmitidos pelo aparato cognitivo humano (BLACKMORE, 2002). Nos anos 2000, vistos como artefatos culturais típicos da cultura participativa (JENKINS, 2009), tiveram dimensão local e global destacada dentro da web (RECUERO, 2007). E hoje associados às redes sociais, vinculam padrões de composição e propósitos multimodais, sendo identificados como memes de internet (SOUZA JUNIOR, 2014).

Com efeito, a internet tornou-se o local mais fecundo para memes, que são vistos como são intricados informacionais que só fazem sentido num contexto (CHAGAS, 2016). Conforme Fontanella (2009, p.8) os memes, originados de determinados "aspectos sociais, culturais, temporais, espaciais", são percebidos como “ideias, jogos, brincadeiras, piadas ou comportamentos" que se alastram por sua replicação de maneira massiva. 0 meme de internet mostra não apenas o repertório individual e cultural de seu criador, mas também daquele que o compartilha. Além disso, ao incorporar elementos como o remix (versão alternativa de obra original que foi alterada ou recombinada para outro contexto) e o humor ridiculariza ideologias, influenciando uma rede de contatos (CHAGAS, 2016).

Se a princípio as tecnologias digitais possibilitaram que os sujeitos se apropriassem mais facilmente dos produtos de entretenimento; em um segundo momento, exigiu deles saberes necessários para poder acessá-los. E, reiterando-se a importância dos usuários na cultura participativa e na produção de excedente cognitivo, mais que um ato criativo que acumula preferências individuais, a produção desse artefato abarca questões sociais (JENKINS, 2009; ESCALANTE, 2016). Nesse sentido, o meme de internet tem exigido dos indivíduos conhecimentos de diferentes 


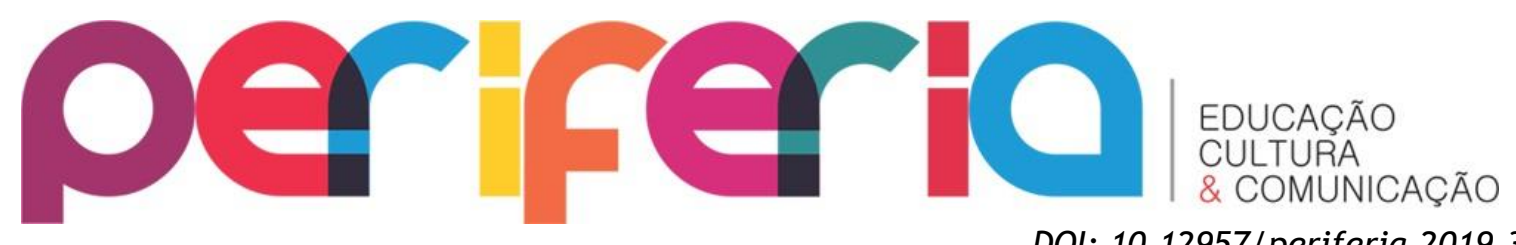

DOI: $10.12957 /$ periferia.2019.37016 campos, ou seja, para compreender seu conteúdo, é necessário ser capaz de combinar criticamente diferentes recursos visuais em diversos gêneros discursivos.

\subsection{Taxonomia dos memes de internet}

Retornando às origens do termo, Dawkins (1978) ao construir o conceito de meme apontou como características inerentes ao gênero: a fidelidade à ideia (capacidade de retenção dos atributos originais de uma peça), a longevidade (tempo de sobrevivência de uma peça, ou seja, sua chance de se replicar) e a fecundidade (quantidade de replicações de um meme e sua velocidade). Sem descartar esses princípios, mas considerando os impactos das tecnologias digitais, Recuero (2007) viu a necessidade de se avaliar o alcance que as peças possuem na rede, ou seja, os tipos de nós que uma peça atinge. Conforme a autora, a propagação de um meme de internet está diretamente relacionada ao capital social de alguns sujeitos. Assim, a influência, a popularidade e o poder de autoridade de determinados atores sociais em suas comunidades on-line são fatores para se compreender como os intricados se alastram.

Com efeito, o capital social reunido por essas comunidades é estimulado pelas diversas postagens, que convergem o estado afetivo de um indivíduo aos estados afetivos daqueles com quem dialoga. Nesse aspecto, o meme de internet está ainda imbuído de valor simbólico, já que representa a encenação que transmite determinadas ideologias culturais (BARRETO, 2015). De acordo com Recuero (2007) as unidades de imitação disseminadas dentro de uma comunidade on-line possuem aspecto agregador, já que os comentários tecidos a partir deles proporcionam o estreitamento dos vínculos sociais, diminuindo as distâncias sociais e instituindo outros grupos.

Isso exposto, ressalta-se que uma propriedade intrínseca dos memes é a intertextualidade, já que são vistos como: a) itens digitais com características semelhantes de conteúdo, forma e postura; b) peças criadas pelos usuários com conhecimento em outras peças; e c) objetos imitados, transformados e distribuídos pela internet (SHIFMAN, 2014). 


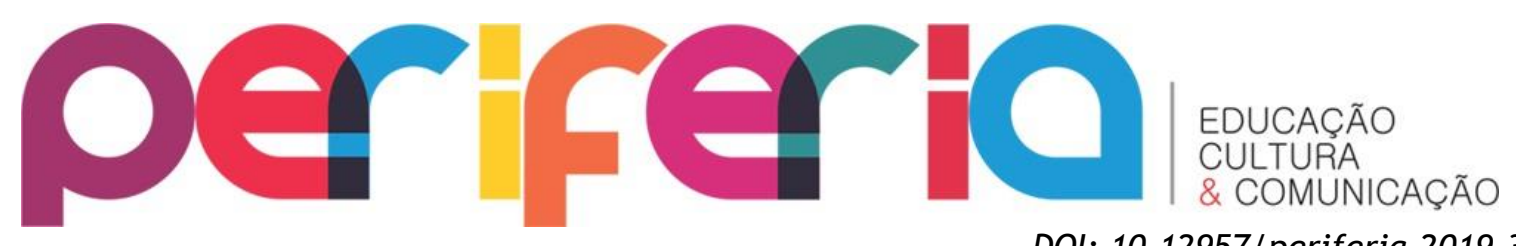

O meme de internet ainda pode ser classificado de acordo com seu conteúdo ou intenção comunicativa, sendo: a) persuasivo, peça publicitária que incorpora o discurso do convencimento; b) de ação popular, frase de efeito, que indica um comportamento coletivo repetido ou pose de foto, que se replica em situações e cenários diferentes; e c) ou de discussão pública, peça de informação que incorpora referências intertextuais e humor crítico (SHIFMAN, 2014).

0 meme persuasivo, considerado mais institucional, possui retórica propositiva, crítica ou ético-moral. Há nele apelo emocional e ideológico, que apela ao pragmático e à credibilidade da fonte. No de ação popular, a conexão é híbrida e o engajamento relativo. Nesse caso, a atuação coletiva é tradicional, sendo as redes administradas por organizações. Já o meme de discussão pública recorre ao lugarcomum da política. Ele traz gracejos sobre personalidades, mostra alusões literárias, apresenta piadas situacionais ou incorpora elementos do humor. Para que um meme de discussão pública seja compreendido, é necessário que o interlocutor tenha informações prévias do assunto, seja capaz de apreender vários significados de uma palavra em determinado contexto, identifique o uso palavras com significados opostos e perceba o emprego de significantes semelhantes com significados diferentes (CHAGAS et al, 2014).

\subsection{Os usos sociais da leitura e da escrita}

O uso das tecnologias digitais levou a formas comunicativas revolucionárias e a gêneros textuais originais. Nesse cenário, Ribeiro (2013) afirma que, na cibercultura, muitos textos já nascem verbo-visuais, ou seja, são constituídos por palavras e imagens desde sua origem.

Sob esse ponto de vista, ser letrado significa adotar mudanças nas maneiras de ler e escrever códigos verbais e não verbais na cultura da tela. Para Euzébio e Cerutti-Rizzatti (2013), o uso da variedade escrita da língua se modificou ao longo do tempo, deixando de ser considerado um conjunto de habilidades individuais para abarcar os expedientes socioculturais contextualizados historicamente. Paralelamente, Soares (2002) e Xavier (2005) admitem que as tecnologias digitais 


\section{periferio mogeso}

DOI: $10.12957 /$ periferia.2019.37016 reorganizaram os espaços da leitura e da escrita, criando outras relações entre escritor e texto, entre escritor e leitor, entre leitor e texto.

Desse modo, conforme as demandas sociais, o emprego da leitura e da escrita compreende as práticas e os eventos. De acordo com Barton e Hamilton (2000 apud EUZÉBIO E CERUTTI-RIZZATTI, 2013, p.19), se as práticas são a base do iceberg, caracterizando-se pelas vivências ancoradas nos usos da escrita e envolvendo "valores, atitudes, sentimentos e relações sociais"; os eventos são sua ponta, possuindo papel e definindo-se como episódios observáveis resultantes das práticas. Se as práticas estão associadas às regras reguladoras do uso e compartilhamento de textos, indicando quem os produz e quem tem acesso a eles; os eventos estão relacionados às rotinas, ora dando início a procedimentos formais de instituições sociais, ora instituindo-se em vivências informais, originadas do ambiente doméstico.

Os eventos envolvendo o uso social da leitura e da escrita possuem quatro elementos visíveis: participantes, ambientes, artefatos e atividades. Conforme Hamilton (2000 apud EUZÉBIO e CERUTTI-RIZZATTI, 2013, p. 22), os participantes são os indivíduos que interagem com a produção escrita; os ambientes relacionam às ocorrências concretas nas quais a interação advém; os artefatos correspondem às ferramentas envolvidas na interação e, finalmente, as atividades equivalem às ações concretizadas pelos participantes no uso competente da leitura e da escrita na prática social.

Considerando esse entendimento, os usos sociais da leitura e da escrita associam-se tanto a instituições formais como a aspectos da vida cotidiana não regularizados por procedimentos formais. E, apesar de algumas práticas de leitura e da escrita serem mais visíveis que outras, suas fronteiras são permeáveis e mutáveis, estabelecendo diálogos entre si (EUZÉBIO E CERUTTI-RIZZATTI, 2013).

$E$, é nessa conjuntura que surge o meme de internet, cerne deste artigo. Identificado normalmente pela combinação de imagens e legendas bem-humoradas, o gênero se alastrou rapidamente pela web, sendo sua repercussão percebida pela recorrência de transmissões, comentários ou imitações por blogs, sites, redes sociais e chats (CHAGAS, 2016). 


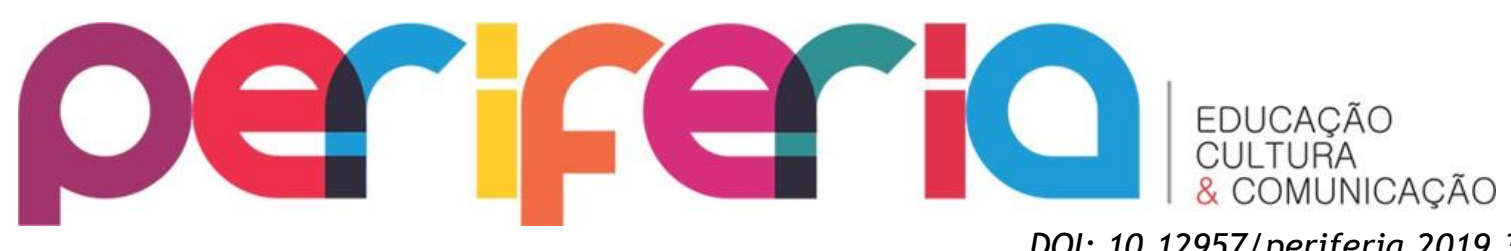

DOI: $10.12957 /$ periferia.2019.37016

Ao longo desses parágrafos, pretendeu-se realizar uma síntese das principais contribuições acadêmicas sobre meme, com a intenção de revisitar conceitos e apresentar sua taxonomia. É relevante perceber que um meme de internet tem como referência não só o repertório individual e cultural de seu criador, como também o conjunto de conhecimento daqueles que o compartilha.

\section{MEMES DE INTERNET NAS AULAS DE HISTÓRIA E LÍNGUA PORTUGUESA: UMA EXPERIÊNCIA INTERDISCIPLINAR}

Se o contexto social coloca as tecnologias digitais como componente do currículo escolar, é imperativo que os educandos sejam orientados a utilizá-las a fim de responder perguntas ou resolver problemas. De acordo com SALES (2010, p. 16), “o currículo escolar se destaca como artefato de grande importância na produção de subjetividades, pois os adolescentes e jovens vivenciam os currículos escolares em boa parte de seu tempo, e esses currículos ensinam, entre outras coisas, modos de ser e de viver no mundo".

Sob essa perspectiva, a instituição escolar está em constante construção social, criando uma trama de relações entre os sujeitos ao atribuir funções e hierarquizar espaços. Nesse ambiente, instituído em torno de um conjunto de normas e regras, a aparência homogênea apenas encobre uma miríade cultural, que é resultado de um processo mais amplo que acontece no cotidiano das relações sociais (DAYRELL, 2001). Se a cultura escolar muitas vezes desconsidera as vivências juvenis, condenando seu gosto musical, seu modo de vestir, maneira de comunicar e comportamento; as comunidades virtuais incorporam os vários elementos midiáticos, operando com a linguagem verbal e não verbal de maneira simultânea (SALES, 2010).

Aliás, os adolescentes e jovens que se encontram nas escolas, "vivendo as práticas curriculares; percorrendo as séries, ciclos e graus do ensino; atingindo supostos níveis de desenvolvimento; alcançando certas etapas; cumprindo ou transgredindo normas e regimentos"; também estão na internet, “construindo conhecimentos; aprendendo condutas, valores e comportamentos; experimentando 


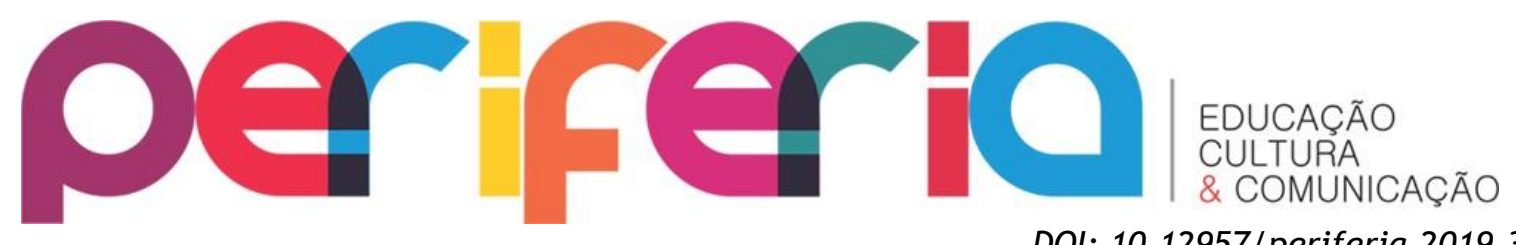

DOI: $10.12957 /$ periferia.2019.37016 diversas práticas de sociabilidade; divertindo-se ou se indignando" (SALES, 2010, p. 51).

Diante disso, fugindo da visão reducionista que muitos indivíduos possuem do meme de internet, uma proposta didática interdisciplinar foi elaborada, tornando esse artefato cultural ferramenta principal de uma sequência de aulas envolvendo os componentes História e Língua Portuguesa. A sequência didática, composta por quatro etapas, foi voltada para os alunos do primeiro ano do ensino médio de uma escola pública da rede estadual do município de Belo Horizonte.

\subsection{Metodologia da sequência didática: trabalhando com memes de internet nas aulas de História e Língua Portuguesa}

Embora, no dia a dia, os adolescentes e jovens naveguem por hiperlinks encontrando todo tipo de informação em diferentes formatos de texto, um ingrediente muitas vezes ausente desse consumo é o enquadramento crítico. Nesse sentido, considerando que a construção de conhecimento se torna mais eficiente quando ocorre de forma colaborativa, as atividades em grupo geram ganhos importantes na aprendizagem, já que as buscas individuais se concentraram apenas na coleta de fatos, enquanto pesquisas colaborativas exploram profundamente as ideias e suas diferentes perspectivas (LEU et al, 2013; ROWSSELL et al, 2013).

Desse modo, com a intenção de promover uma reflexão sobre os acontecimentos que mobilizaram a sociedade brasileira a partir do segundo mandato da presidente Dilma Russef, utilizou-se o conhecimento histórico como instrumento para chegar-se a um discernimento maior sobre os eventos políticos vivenciados pelos brasileiros.

\subsubsection{Apresentação da sequência didática}

A primeira etapa da sequência didática teve como objetivo apresentar a proposta pedagógica envolvendo os componentes História e Língua Portuguesa aos alunos. A simples menção da palavra “meme” causou uma agitação entre os educandos. Nesse momento, foi explicado a eles que o meme configuraria como 


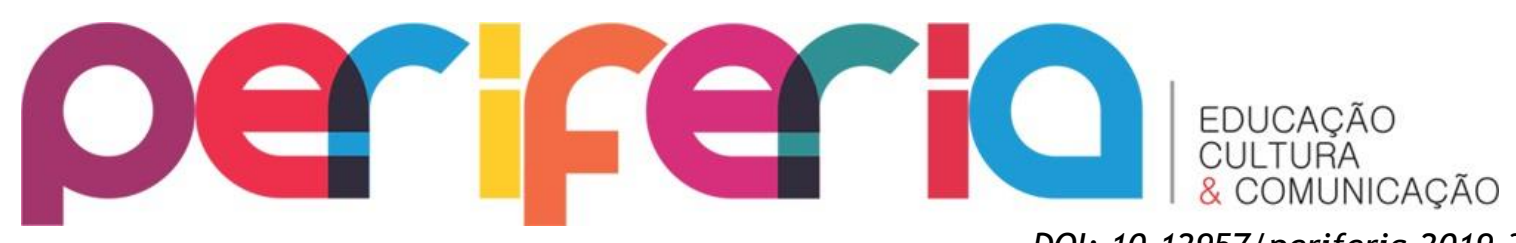

DOI: $10.12957 /$ periferia.2019.37016 representação da situação de comunicação que seria executada (DOLZ, NOVERRAZ E SCHNEUWLY, 2004), cabendo a eles reunir, compreender, analisar, avaliar, sintetizar, relatar informações e ideias, que seriam divulgadas, em mídias antigas e novas, por meio de textos impressos e não impressos (LEU et al, 2013).

Depois dessas explicações, os alunos foram instruídos a realizar pesquisas sobre a crise política brasileira iniciada com o acolhimento do pedido de impeachment de Dilma Russef pelo presidente da Câmara dos Deputados, Eduardo Cunha. Os estudantes ainda foram orientados a investigar sobre os desdobramentos da Operação Lava Jato, que levou à prisão vários parlamentares, ex-ministros e empresários e refletir sobre o papel da mídia na divulgação de todo processo.

Os aprendizes foram orientados a buscar fontes confiáveis, verificando como a mesma notícia era apresentada em pelo menos três veículos de comunicação diferentes. Além da indicação de alguns sites, houve a preocupação em preparar os aprendizes para reconhecer notícias sensacionalistas. Na sequência, cada turma foi dividida em grupos de alunos, que puderam escolher um evento a partir do contexto determinado. Para concluir essas explicações sobre a proposta foram necessárias duas aulas.

Durante duas semanas, os adolescentes realizaram pesquisas sobre o assunto escolhido, preparando-se para o debate. As investigações realizadas pelos alunos foram realizadas como tarefa de casa. Nesse tempo, foram realizados esclarecimentos pertinentes às dificuldades de cada turma.

\subsubsection{Considerações teóricas sobre o meme de internet}

A segunda parte da sequência didática se caracterizou pela capitalização das aquisições dos alunos. Nessa ocasião, durante os debates, pôde-se aferir o desempenho linguísticos dos aprendizes e os conhecimentos adquiridos por meio das pesquisas. Assim, o acontecimento histórico serviu como instrumento para se questionar o presente, promovendo uma participação crítica dos estudantes durante as discussões. Os debates aconteceram nas aulas de História ao longo de uma 


\section{per
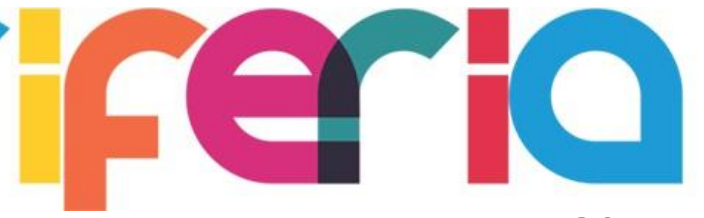 \\ EDUCAÇÃO \\ CULTURA \\ \& COMUNICAÇÃO}

DOI: $10.12957 /$ periferia.2019.37016

semana, mas com repercussões em Língua Portuguesa, uma vez que os alunos recorriam ao conteúdo para construir diferentes posições e argumentos.

Em duas aulas, envolvendo os componentes História e Língua Portuguesa, discutiu-se com os alunos os elementos constitutivos de um meme. Também foi analisado como determinado meme ou expressão memética se mostravam favoráveis ao aparecimento de novas peças (SOUZA JÚNIOR, 2015). Aliás, os educandos perceberam que grande parte dos memes apresentavam construção multimodal, isto é, uma imagem, distribuída digitalmente, de maneira multimidiática, vinculada a uma legenda e cumprindo com fins sistematizados pela linguagem (SOUZA JÚNIOR, 2014).

\subsubsection{Produção do meme a partir das discussões em classe}

A terceira parte da sequência didática foi dedicada à criação dos memes. Os alunos foram orientados a criar peças que reunissem noções e ensinamentos adquiridos durante as duas etapas da sequência didática. Para essa tarefa, a sala de informática da escola foi disponibilizada para os alunos no contraturno escolar. No entanto, o que se observou que a maioria dos grupos desenvolveram as tarefas em seus próprios lares.

Cada grupo teve uma semana para confeccionar seus produtos. Não houve a necessidade de se promover explanações sobre como construir um meme, pois, foi observado que, essa era uma prática comum aos adolescentes e jovens. No entanto, durante esse período, nas aulas de Língua Portuguesa, os alunos tiveram contato com as proposições de Michael Alexander Halliday (1987 apud SOUZA JÚNIOR, 2014) sobre a linguagem.

Pela teoria das metafunções, os aprendizes compreenderam que, na produção multimodal, existe uma organização e estrutura dos elementos visuais, ou seja, “alguns elementos representados aparecerão na frente e outros no fundo do cenário da imagem; uns iluminados e outros completamente foscos ou borrados; podem existir itens colocados no centro e outros nas margens" (SOUZA JÚNIOR, 2015, p. 11. Grifo do autor). 


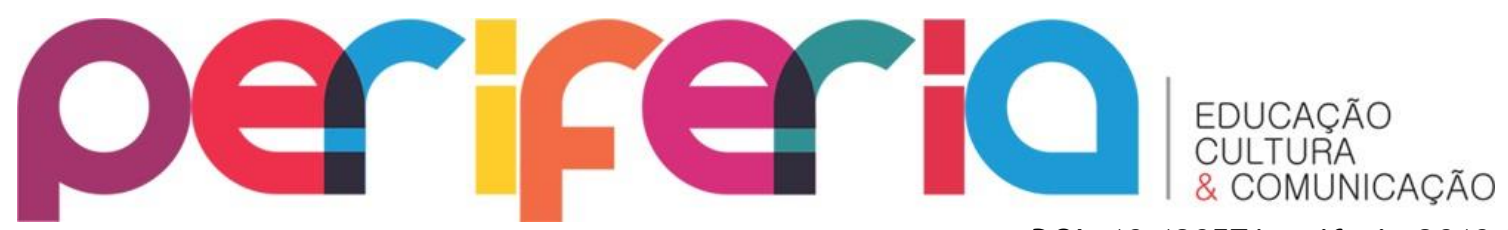

DOI: $10.12957 /$ periferia.2019.37016

As personalidades já conhecidas por eles representavam circunstâncias que motivaram as discussões dos debates. Nessa direção, o meme se mostrou como “meio" e "palco" de produção de saberes históricos e educacionais que permitiram aos adolescentes confrontar experiências significativas de sua existência (CUNHA E PRADO, 2017).

$\mathrm{Na}$ confecção das peças, os alunos tiveram como suporte a internet. Recorrendo a aplicativos de geradores de meme ou utilizando softwares para edição de imagens de seus computadores pessoais, os educandos associaram textos e imagens disponíveis na web a situações da política brasileira, conforme pode se verificar na figura 1.

Figura 1. Meme de internet, produzido por grupo de alunos na terceira fase da sequência didática, tem como conteúdo a Operação Carne Fraca. Deflagrada pela Polícia Federal (PF) no âmbito da Lava Jato, a operação investigou o esquema de propina entre a empresa JBS e políticos brasileiros responsáveis por liderar a nação.

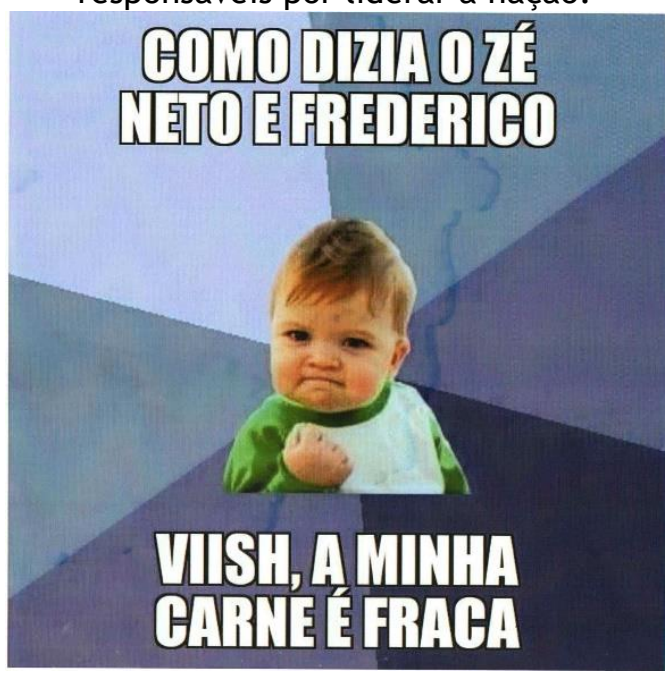

Fonte: Própria.

O meme acima tem como base uma imagem bem conhecida na internet: Sam Grimer com os punhos cerrados quando quando tinha 11 meses de idade. Em 2007, a foto postada pela mãe do menino, no MySpace, tornou-se viral. Grimer teve seu rosto espalhado pelas redes sociais associado a legendas diversas. Na peça elaborada pelos alunos envolvidos na sequência didática, a alusão ao momento histórico brasileiro se dá pela imagem de Grimer associada às frases "Como dizia o Zé Neto e Frederico", que se refere à dupla de cantores sertanejos formada pelos irmãos João Neto Nunes 


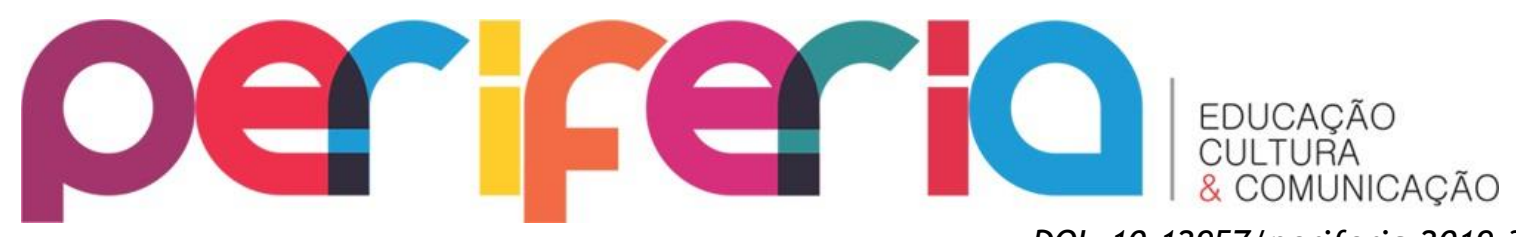

DOI: $10.12957 /$ periferia.2019.37016 e Frederico Nunes² e "Viish, a minha carne é fraca", uma alteração do verso de "Não tô valendo nada" 3 , música sertaneja de maior destaque no ano de 2013, interpretada pela dupla. Nota-se que além da intertextualidade, esse meme traz as marcas de outro produto cultural muito consumido pelos adolescentes e jovens - a música. Percebe-se que, na produção, os aprendizes associaram os versos da canção à operação deflagrada pela Polícia Federal.

$\mathrm{Na}$ realização da tarefa, houve grande envolvimento dos educandos com a proposta pedagógica, sendo que vários grupos produziram mais de uma peça. Para encerrar a sequência didática, os memes criados pelos grupos foram apresentados numa exposição para apreciação de toda turma.

\subsubsection{Exposição dos memes produzidos}

A última parte da sequência didática, aconteceu em cada turma, durante a aula de Língua Portuguesa. Para a exposição, cada grupo providenciou a impressão de sua peça, que foi afixada nas paredes da própria sala de aula (Figura 2). Coube a cada estudante apreciar as produções alheias, tecendo comentários ou questionando os produtores sobre as intenções da peça quando não conseguiam decodificar sua mensagem.

\footnotetext{
2 Observa-se o equívoco dos estudantes em relação ao nome da dupla sertaneja.

${ }^{3} \mathrm{Na}$ composição de Henrique \& Juliano, o verso original traz "Vish, como a minha carne anda é fraca".
} 


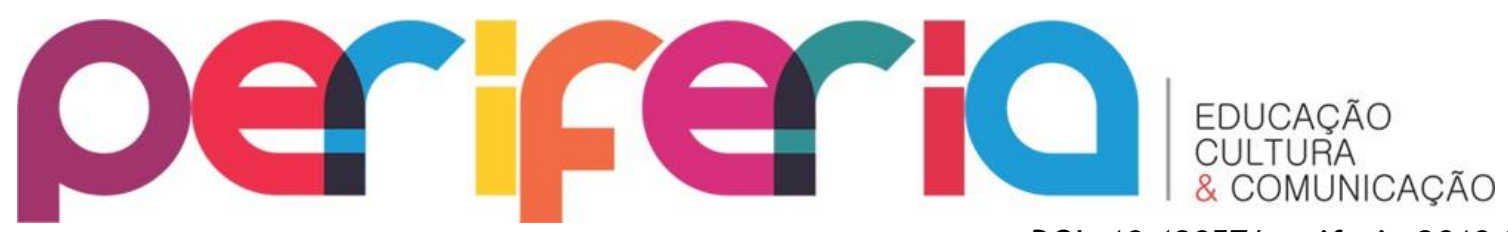

DOI: $10.12957 /$ periferia.2019.37016

Figura 2. Exposição dos memes criados pelos alunos no encerramento da sequência didática promovida pelos componentes curriculares História e Língua Portuguesa, em julho de 2017.

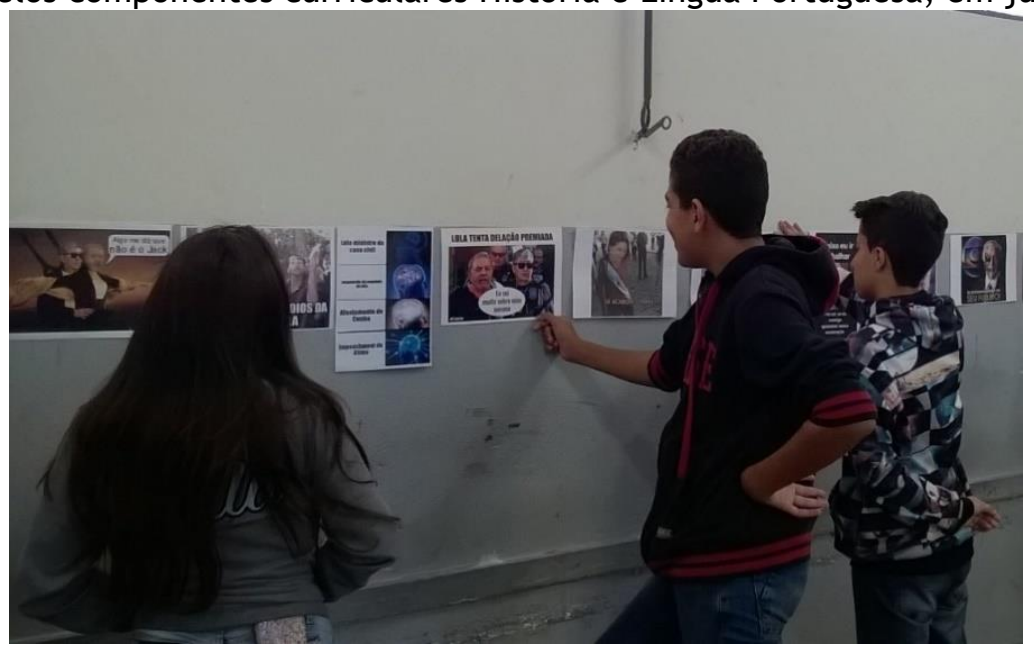

Fonte: Própria.

Durante a exposição, houve a análise das representações visuais, levando o aprendiz a perceber que há de se considerar tanto as categorias narrativas como as conceituais. Em outras palavras, nos processos narrativos são admitidos as circunstâncias (instrumento, local, companhia) e os participantes (seres humanos ou não), que fazem algo para alguém ou recebem algo de alguém; já nos processos conceituais, os participantes existem, estão associados, são superiores ou subordinados a outros elementos visuais (Kress e Van Leeuwen, 2000 apud SOUZA JÚNIOR, 2014).

\subsection{Avaliando os resultados da sequência didática}

Diante dessa sequência didática, os aprendizes compreenderam que impregnado de intertextualidade, o meme demanda de quem o interpreta vários saberes. Diante de uma peça, que se caracteriza pelo compartilhar, imitar e remixar (SHIFMAN, 2014), compreendem-se não apenas as tendências culturais de seus criadores, suas identidades individuais; mas também a essência da cultura participativa, atribuída pelo sentimento de pertença das identidades a grupos coletivos específicos. Indubitavelmente as ideias apenas sobrevivem porque conseguem ser transformadas, reaproveitadas ou distorcidas ao passarem por uma variedade de indivíduos (JENKINS, 2009; CANEN, 2015). 


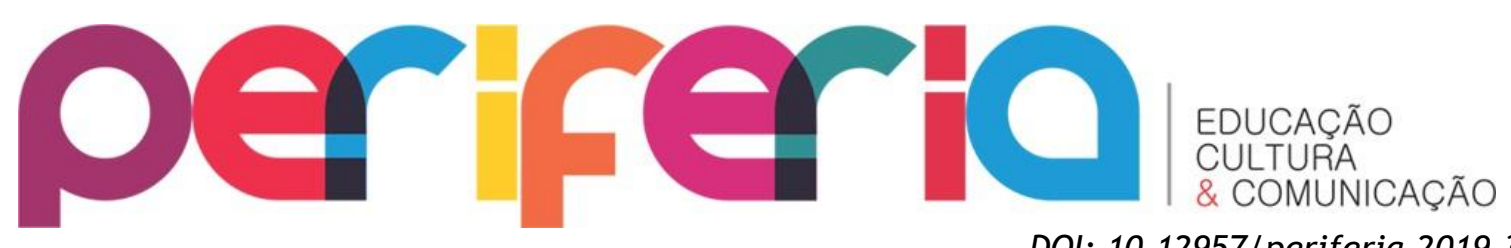

DOI: $10.12957 /$ periferia.2019.37016

Ao analisar os memes produzidos pelos alunos, foi possível observar que nenhum deles apresentou discurso de ódio, provando que os adolescentes souberam discernir os limites entre liberdade de expressão e agressão a direitos constituídos. As peças criadas pelos adolescentes e jovens sempre bem espirituosas, diziam do momento político vivenciado por eles. Foi constado ainda que para se construir os significados dos memes, os produtores identificaram o gênero do discurso a partir do suporte e das categorias formais, entenderam como se encadeavam as sequências tipológicas e estabeleceram coerência a partir das escolhas léxicas utilizadas.

Os memes produzidos pelos aprendizes possuíam uma linguagem simples à primeira vista. No entanto, as peças vinculam singularidades de diversos campos do saber, instigando novas práticas sociais que envolvem aprendizado, leitura e escrita. Embora a escrita de um meme não precisasse adotar a norma culta da língua, exigiu dos produtores outras habilidades como utilizar softwares de edição e familiaridade com a plataforma usada. (COSCARELLI, 2006; ESCALANTE, 2016, CHAGAS, 2016).

Recorrendo a elementos da análise propagatória, pelo princípio do design, averiguou-se como ocorreu a reelaboração de determinado item. Nas peças produzidas, percebeu-se esse remix a partir do momento em que um meme foi ressignificado para originar novas peças. Essa proposta de análise ainda reuniu o estudo de imagem e texto, considerando as compreensões da linguística sistêmicofuncional, de Kress e Van Leeuwen (SOUZA JÚNIOR, 2014).

Embora o texto de um meme não precise adotar a norma culta da língua, exige dos usuários outras habilidades como utilizar softwares de edição e familiaridade com a plataforma usada. Conforme Escalante (2016, p. 93), a leitura de uma peça envolve "saber ler, saber em qual língua o meme está escrito, conhecer as referências culturais que estarão presentes nele, saber manusear o aparato técnico em que ele está exposto etc."

Nessa seção, apresentou-se os resultados de uma sequência didática desenvolvida com estudantes do primeiro ano do ensino médio de uma escola pública da rede estadual do município de Belo Horizonte. A proposta didática foi apresentada para ilustrar as teorias que compreendem o meme de internet como um artefato cultural. Paralelamente a essas concepções, foi salientado que a produção de um 


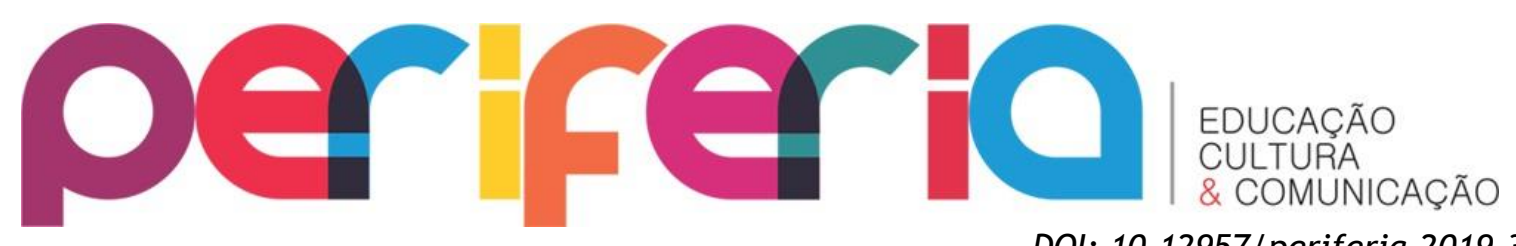

meme considera tanto as referências internas à obra como as de outros artefatos culturais externos a ela ou circunstâncias políticas, sociais e históricas.

\section{CONSIDERAÇÕES FINAIS}

Este artigo teve como intenção reunir as principais contribuições acadêmicas sobre meme de internet, mostrando que o gênero além de vincular singulares campos do conhecimento, demanda dos sujeitos habilidades para usufruir, criar e compartilhar peças. Ao longo do texto, foram mencionadas as particularidades do meme de internet e salientado seu caráter intertextual. Paralelamente a essas observações, concepções a respeito das práticas e eventos de letramento foram abordadas.

O trabalho apresentou o meme de internet enquanto artefato cultural que considera participantes do discurso, elementos da enunciação, situações e intenções comunicativas, num intricado que só faz sentido dentro de um contexto sociocultural. 0 gênero ainda foi identificado como forma de expressão da cultura digital, evidenciando seu caráter complexo que não apenas compartilha um conteúdo, mas estabelece conexões.

0 desafio deste estudo foi reunir teorias que abarcassem o meme de internet não apenas como artefato relacionado à cultura juvenil, mas também como elemento motivador de determinadas práticas pedagógicas. Hoje se reconhece que é necessário repensar o ensino, uma vez que ele não tem atendido os anseios das novas gerações. Nesse contexto, não se pode pensar que um gênero seja inferior a outro: uma conferência é tão importante quanto um meme, uma vez que atribuem sentidos distintos a situações diferentes.

Este artigo ainda mostrou uma sequência didática desenvolvida entre os componentes História e Língua Portuguesa com estudantes do primeiro ano do ensino médio de uma escola pública da rede estadual do município de Belo Horizonte. A proposta didática foi analisada para ilustrar que o fato histórico pode funcionar como instrumento para chegar-se a um discernimento maior sobre os acontecimentos 


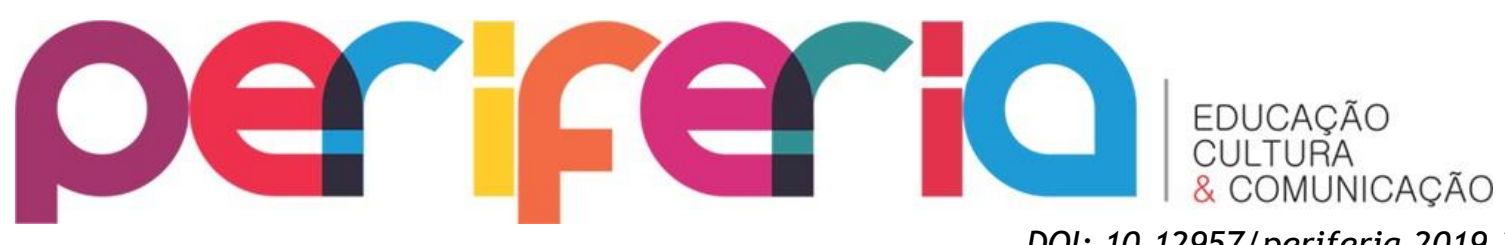

DOI: $10.12957 /$ periferia.2019.37016 políticos e que muito do que se produz em relação a gêneros digitais em circulação está relacionado a fenômenos de remix, apropriação e compartilhamento.

\section{REFERÊNCIAS}

BARRETO, Krícia Helena. Os memes e as interações sociais na internet: Uma interface entre práticas rituais e estudos de face. Tese (doutorado) - Universidade Federal de Juiz de Fora, Faculdade de Letras. Programa de Pós-Graduação em Linguística, 2015. Disponível em http://www.ufjf.br/ppglinguistica/files/2009/12/BARRETO-Kr\%C3\%ADcia-HelenaTESE-2015.pdf. Acesso em 2 nov. 2017

BLACKMORE, Susan. A evolução das máquinas de memes. In: International Congresss On Ontopsychology, 2002, Milão. [Anais...]. Milão: International Ontopsychology Association, 2002. Disponível em: <http://www.susanblackmore.co.uk/Conferences/ OntopsychPort.htm>. Acesso em: 2 ago. 2017.

CANEN, Ana. O multiculturalismo e seus dilemas: implicações na educação. In: Comunicação\&tpolítica, v.25, n², p.091-107 2015.

CHAGAS, Viktor et al. A política dos memes e os memes da política: proposta metodológica de análise de conteúdo de memes dos debates eleitorais de 2014. In: Intexto, Porto Alegre, UFRGS, n. 38, p. 173-196, jan./abr. 2017. Disponível em http://seer.ufrgs.br/index.php/intexto/article/view/63892 Acesso em 2 nov. 2017

- A febre dos memes de política. In: Trabalho apresentado no GT 17 Mídias, Política e Eleições da $40^{\circ}$ Encontro Anual da Associação Nacional de PósGraduação e Pesquisa em Ciências Sociais (ANPOCS) em Caxambu, Minas Gerais, 2016.

COSCARELLI, Carla Viana. Os dons do hipertexto. Littera: Revista de Linguística e Literatura. Pedro Leopoldo: Faculdades Integradas Pedro Leopoldo, v.4, n.4, jul/dez, 2006. p.7-19. Disponível em http://www.letras.ufmg.br/carlacoscarelli/publicacoes/DonsDoHipertexto.pdf Acesso em 25 mai. 2017

CUNHA, Nara Rúbia de Carvalho; PRADO, Guilherme do Val Toledo. Memórias e sensibilidades numa produção de conhecimentos histórico-educacionais. In: Revista Memória em Rede, Pelotas, v.10, n.17, Jul./Dez.2017.

DAYRELL, Juarez Tarcísio. Múltiplos olhares sob a educação e cultura. 2. Reimpressão. Belo Horizonte: UFMG, 2001. 


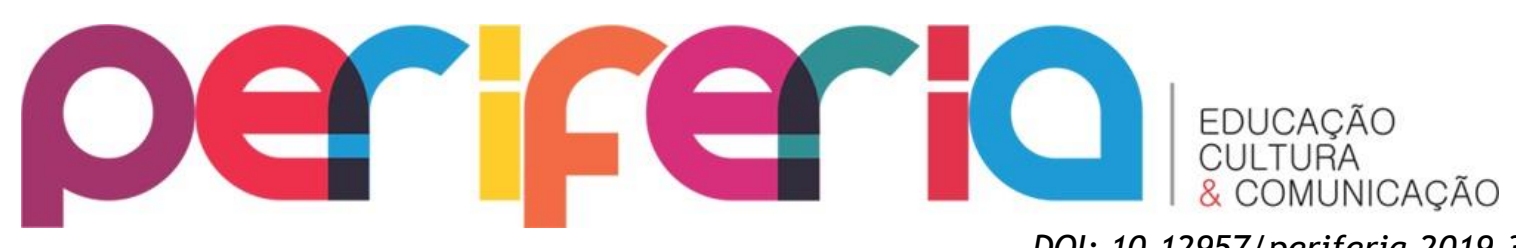

DOI: $10.12957 /$ periferia.2019.37016

DAWKINS, Richard. O Gene Egoísta. Trad. Geraldo Florsheim, Belo Horizonte:

Editora Itatiaia; São Paulo: Universidade da Universidade de São Paulo, 1978.

DENNETT, Daniel C. Memes: Myths, Misunderstandings and Misgivings. DRAFT. for Chapel Hill, October 1998. Disponível em

https://ase.tufts.edu/cogstud/dennett/papers/MEMEMYTH.FIN.htm. Acesso em 12 jan. 2018

DOLZ, J.; NOVERRAZ, M.; SCHNEUWLY, B. Sequências didáticas para o oral e a escrita: apresentação de um procedimento. In: DOLZ, J.; SCHENEUWLY, B. Gêneros orais e escritos na escola. Tradução de Roxane Rojo e Gláis Sales Cordeiro (Org.). Campinas: Mercado das Letras, 2004.

ESCALANTE, Pollyana Rodrigues Pessoa. O potencial comunicativo dos memes: formas de letramento na rede digital. Dissertação (Mestrado) - Universidade do Estado do Rio de Janeiro. Faculdade de Comunicação Social, 2016. Disponível em http://www.ppgcom.uerj.br/wp-content/uploads/Disserta\%C3\%A7\%C3\%A3oPollyana-Escalante.pdf. Acesso em 2 nov. 2017

EUZÉBIO, Michelle Donizeth; CERUTTI-RIZZATTI, Mary Elizabeth. Usos Sociais da Escrita: Um Estudo sobre Práticas e Eventos de Letramento na Vivência de Professoras Alfabetizadoras. In: Linguagem em (Dis, Tubarão, SC, v. 13, n. 1, p. 1334, jan./abr. 2013. p. 13-34.

FONTANELLA, Fernando. O que é um meme na Internet? Proposta para uma problemática da memesfera. Trabalho apresentado no III Simpósio Nacional da ABCiber, São Paulo, 2009.

FRAGOSO, Suely; RECUERO, Raquel; AMARAL, Adriana. Métodos de pesquisa para internet. Porto Alegre: Sulina, 2011.

JENKINS, Henry. Cultura da Convergência. Aleph, 2009; p. 27-53.

LEMOS, André; CUNHA, Paulo (orgs). Olhares sobre a Cibercultura. Sulina, Porto Alegre, 2003; p. 11-23.

LEVY, Pierre. Cibercultura. São Paulo: Ed. 34, 1999.

LEU, Donald J.; KINZER, Charles K.; COIRO, Julie; CASTEK, Jill; HENRY, Laurie A. Novas literacias: uma teoria de duplo nível da natureza mutável da alfabetização, Instrução e Avaliação. In: Theoretical models and processes of reading. Newark, DE: International Reading Association, 2013.

MARCONI, M. A.; LAKATOS, E. M. Metodologia do trabalho científico. 7. ed. São Paulo: Atlas, 2010. 


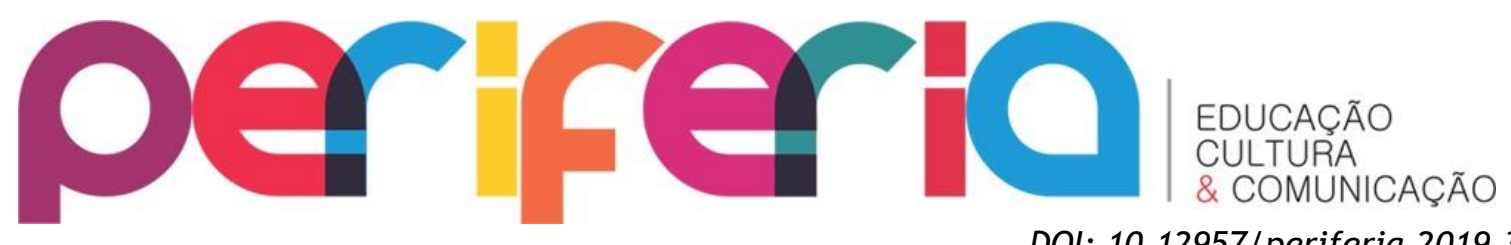

DOI: $10.12957 /$ periferia.2019.37016

RECUERO, Raquel da Cunha. Memes em weblogs: proposta de uma taxonomia. Revista FAMECOS, Porto Alegre, n. 32, p. 23-31, abril de 2007.

RIBEIRO, Ana Elisa. Multimodalidade e Produção de Textos: Questões para o Letramento na Atualidade. In: Signo [ISSN 1982-2014]. Santa Cruz do Sul, v. 38, n. 64, p. 21-34, jan./jun. 2013. Disponível em http://online.unisc.br/seer/index.php/signo. Acesso em 4 nov. 2017

ROJO, R. Letramentos múltiplos, escola e inclusão social. São Paulo: Parábola. Editorial, 2009.

SALES, Shirlei Rezende. Orkut.com.escol@: currículos e ciborguização juvenil. Tese - (Doutorado) - Universidade Federal de Minas Gerais, Faculdade de Educação. UFMG/FaE, 2010. Disponível em http: / / www.bibliotecadigital.ufmg.br/dspace/bitstream/handle/1843/FAEC8M4H42/orkut.com.escol_curr_culos_e_ciborguiza_o_juvenil.pdf?sequence $=1$ Acesso em 2 nov. 2017.

SHIFMAN, Limor. Memes in Digital Culture. MIT press, 2014.

SOARES, Magda. Novas práticas de leitura e escrita: letramento na cibercultura. In: Educ. Soc., Campinas, vol. 23, n. 81, p. 143-160, dez. 2002 Disponível em http://www.scielo.br/pdf/es/v23n81/13935.pdf Acesso em 11 mai. 2017

SOUZA JÚNIOR, J. de. Memes pluralistas - práticas linguístico-midiáticas em fenômenos bilíngues: um estudo sistêmico-funcional e multimodal sobre propagação via corpora digitais. 2014. 173 f. Dissertação (Mestrado em Linguística) - Instituto de Letras, Universidade do Estado do Rio de Janeiro, Rio de Janeiro, 2014.

XAVIER, Antonio Carlos dos Santos. Letramento Digital e Ensino. In: Carmi Ferraz Santos e Márcia Mendonça. (Org.). Alfabetização e Letramento: conceitos e relações. 1ed. Belo Horizonte: Autêntica, 2005, v. 1, p. 133-148. 